\title{
Do Hernias Contribute to Increased Severity of Aneurysmal Disease among Abdominal Aortic Aneurysm Patients?
}

\author{
Irene Hinterseher, MD ${ }^{1, *(1)}$ Milena Miszczuk, MD ${ }^{1, *(1)}$ Florian Corvinus, $\mathrm{MD}^{2}$ \\ Carolin Zimmermann, $\mathrm{MD}^{3}$ Mariana Estrelinha, $\mathrm{MD}^{4}$ Diane T. Smelser, $\mathrm{PhD}^{5}$ (1) \\ Helena Kuivaniemi, MD, $\mathrm{PhD}^{6}$ \\ 1 Vascular Surgery Clinic, Charité-Universitätsmedizin Berlin, \\ corporate member of Freie Universität Berlin, Humboldt-Universität \\ zu Berlin, and Berlin Institute of Health, Berlin, Germany \\ 2 Department of General, Visceral and Transplant Surgery, \\ Universitätsmedizin Mainz, Mainz, Germany \\ ${ }^{3}$ Department of Visceral, Thoracic and Vascular Surgery, University \\ Hospital Carl Gustav Carus, Technical University of Dresden, \\ Dresden, Germany \\ ${ }^{4}$ Clinic of Vascular and Endovascular Surgery, Ludwigsburg, Germany \\ Address for correspondence Irene Hinterseher, MD, Vascular Surgery \\ Clinic, Charité Universitätsmedizin Berlin -Campus Benjamin Franklin, \\ Hindenburgdamm 30, Berlin, 12200, Germany \\ (e-mail: irene.hinterseher@charite.de). \\ ${ }^{5}$ Sigfried and Janet Weis Center for Research, Geisinger Health \\ System, Danville, Pennsylvania \\ ${ }^{6}$ Division of Molecular Biology and Human Genetics, Department of \\ Biomedical Sciences, Faculty of Medicine and Health Sciences, \\ Stellenbosch University, Tygerberg, South Africa \\ Aorta (Stamford) 2021;9:9-20.
}

\begin{abstract}
Keywords

- abdominal aortic aneurysm

- hernia

- connective tissue disorder

Background Connective tissue disorders could contribute to the pathogenesis of both abdominal aortic aneurysms (AAA) and hernias. We tested the hypothesis that hernias in AAA patients contribute to increased severity of the aneurysmal disease.

Methods A questionnaire was used to collect information from 195 AAA patients divided into four groups: (1) survivors $(n=22)$ of ruptured AAA, (2) patients $(n=90)$ after elective open repair, (3) patients $(n=43)$ after elective endovascular repair (EVAR), and (4) patients $(n=40)$ under surveillance of AAA. The control group consisted of 100 patients without AAA whose abdominal computed tomography (CT) scans were examined for the presence of hernias. Mann-Whitney U-test, Chisquared $\left(x^{2}\right)$ test, or Fisher's exact test (as appropriate) were used for statistical analyses. Multivariate logistic regression was used to control for potential confounding variables such as sex and age.

Results The prevalence of inguinal hernias was significantly higher in the AAA than the control group ( 25 vs. $9 \%, p=0.001$ ) and did not differ between the AAA subgroups $(9,24,35$, and $23 \%$ in subgroups 1 through 4 , respectively, $p=0.15)$ based on univariate analysis. The prevalence of inguinal hernias did not differ $(p=0.15)$ between the two open surgery groups (groups 1 and 2), or when comparing all three operative procedures as a combined group to group $4(p=0.73)$. The prevalences of incisional hernias were 18 and $24 \%$ for groups 1 and 2 , respectively, with no significant difference
\end{abstract}

* These authors contributed equally to this work

received

June 12, 2019

accepted after revision

October 2, 2020
DOI https://doi.org/

$10.1055 / \mathrm{s}-0040-1719113$.

ISSN 2325-4637. (c) 2021. The Author(s).

This is an open access article published by Thieme under the terms of the Creative Commons Attribution License, permitting unrestricted use, distribution, and reproduction so long as the original work is properly cited. (https://creativecommons.org/licenses/by/4.0/)

Thieme Medical Publishers, Inc., 333 Seventh Avenue, 18th Floor, New York, NY 10001, USA 
$(p=0.39)$. Inguinal hernia demonstrated a significant association with AAA on multivariate analysis $(p=0.006$; odds ratio $[O R]=4.00$; $95 \%$ confidence interval $[\mathrm{Cl}]=1.49-10.66)$.

Conclusions Our study confirms previous observations that patients with AAA have a high prevalence of hernias. Our results suggest that hernias do not contribute to increased severity of the aneurysmal disease.

\section{Introduction}

Abdominal aortic aneurysm (AAA) is a complex disease of the aging population that affects up to $10 \%$ of Caucasian males over 65 years of age and is a leading cause of death in the United States with approximately 7,000 deaths per year. ${ }^{1}$ Due to improved diagnostic efforts using ultrasonography imaging, AAAs can be identified earlier. Despite improved diagnostic imaging, $15 \%$ of cases present as ruptured AAA in hospitals of industrialized nations. ${ }^{2}$

AAA has several recognized risk factors such as smoking, male sex, age over 65 years, and positive family history. ${ }^{3}$ Additionally, an increased prevalence of AAA was described in patients with pulmonary emphysema, ${ }^{4}$ and patients with AAA have a 2.3- to 3-fold increased risk of developing inguinal hernia compared with patients with aortoiliac occlusive disease (AOD) ${ }^{5,6}$ It is well known that mechanical factors, such as weakening of the abdominal wall after a transperitoneal operation and increased intra-abdominal pressure, increase a person's risk for hernias. Other known risk factors for inguinal hernias include male sex, age over 65 years, smoking, pulmonary emphysema, and family history. ${ }^{7}$ Incisional hernias occur in 5 to $15 \%$ of patients undergoing transperitoneal operations. ${ }^{8}$ Risk factors for incisional hernias include malnutrition, malignancy, wound infection, chronic obstructive pulmonary disease, diabetes mellitus, renal insufficiency, obesity, smoking, and older age. $^{8}$ Thus, AAA patients and patients with the most common forms of hernias of the abdominal wall share many risk factors.

Vascular surgeons are aware of the high risk of developing an incisional hernia after open transabdominal AAA surgery. Furthermore, AAA patients often present with large inguinal hernias or have a history of an inguinal hernia repair. ${ }^{4,6}$ The prevalence of inguinal and incisional hernias among AAA patients was investigated in studies summarized in -Tables 1 and 2. A meta-analysis on several of these studies concluded that the prevalences of inguinal and incisional hernias among AAA patients were 23 and 21\%, respectively. ${ }^{6} \mathrm{~A}$ large retrospective cohort study found that the combined prevalence of all types of abdominal wall hernias was $16.7 \%$ in AAA patients $(n=939)$ compared with $9.9 \%$ in the control group of peripheral arterial disease (PAD) patients $(n=3,465 ; p<0.0001) .{ }^{9}$

The main aim of this study was to determine if hernias contribute to increased severity of the aneurysmal disease. The underlying hypothesis was that AAA is a connectivetissue disorder demonstrating vascular weakness and therefore more advanced stages of the AAA disease (i.e., diameter $>5 \mathrm{~cm}$ or ruptured AAA) are associated with a higher prevalence of hernias.

\section{Materials and Methods}

\section{Patient Groups and Data Collection}

A questionnaire was designed to collect the following information: (1) presence of inguinal and incisional hernias, (2) history of hernia operations, and (3) family history of AAA. The questionnaire was sent to 249 AAA patients treated in the Vascular Center of the University Hospital Carl Gustav Carus, Technical University of Dresden, Germany, from 1995 to 2005. The questionnaire was administered from September to December 2006. The study was approved by the Ethics Committee of the Medical School at the Technical University of Dresden, Germany (EK346112010). According to the institutional guidelines, informed consent for the retrospective data analysis was waived. The questionnaire was completed by 195 (78\%) of the 249 patients. The 195 AAA patients were divided into four groups based on the treatment. The groups reflected the stage and severity of the aneurysmal disease: (1) survivors after open repair of ruptured AAA (rAAA; 22 completed the questionnaire out of 26 who received the questionnaire; participation rate: $85 \%$ ), (2) patients $(n=90 / 98 ; 92 \%)$ who had undergone elective open repair (eAAA), (3) patients $(n=43 / 47 ; 91 \%)$ who had elective endovascular treatment (EVAR), and 4) patients $(n=40 / 78$; $51 \%$ ) with a small AAA under surveillance (sAAA).

Open surgical repair was performed by transperitoneal approach with midline incision. Fascial closure was done for all patients with continuous absorbable suture by experienced vascular surgeons who are all also certified general surgeons. Elective open and endovascular repair of AAA was performed if the aortic diameter was $\geq 5.0 \mathrm{~cm}$. Small AAAs under surveillance had a diameter of 3.0 to $4.9 \mathrm{~cm}$ and were diagnosed by ultrasonography.

Clinical data (prior to the beginning of the study) for the AAA patients were collected from the medical records, and all laboratory measurements were preoperative.

A control group $(n=100)$ consisted of patients with no history of AAA (infrarenal diameter $<3 \mathrm{~cm}$ ) and no other aneurysms. All control patients underwent an abdominal computed tomography angiography (CTA) scan at the Department of Radiology, Charité, Berlin, Germany, in 2005 to 2014 either for evaluation of a kidney donation $(n=14)$ or as part of screening for melanoma recurrence $(n=86)$. We calculated the age at the time of the CTA scan. The CTA scans 
Table 1 Review of literature on association between inguinal hernia and abdominal aortic aneurysms

\begin{tabular}{|c|c|c|c|c|}
\hline \multirow[t]{2}{*}{ Study } & \multirow[t]{2}{*}{ Examination method } & \multicolumn{2}{|c|}{ Inguinal hernia ${ }^{a}$} & \multirow[t]{2}{*}{$p$-Value ${ }^{\mathrm{b}}$} \\
\hline & & $\begin{array}{l}\text { AAA } \\
n(\%)\end{array}$ & $\begin{array}{l}\text { Controls } \\
n(\%)\end{array}$ & \\
\hline Cannon et al ${ }^{27}$ & Clinical & $88 / 341(26)$ & $61 / 417(16)$ & $<0.001$ \\
\hline Lehnert and Wadouh ${ }^{28}$ & Clinical & $49 / 119(41)$ & $15 / 81(16)$ & 0.001 \\
\hline Hall et al ${ }^{29}$ & Clinical & $28 / 128(22)$ & $11 / 65(17)$ & NS \\
\hline Adye and Luna ${ }^{30}$ & Clinical & $11 / 58$ (19) & $2 / 42(5)$ & 0.037 \\
\hline Wright and O'Dwyer ${ }^{31}$ & Clinical & $25 / 149(17)$ & - & - \\
\hline Musella et al ${ }^{32}$ & MRI & $20 / 51(39)$ & $13 / 63(20)$ & 0.01 \\
\hline Papadimitriou et al ${ }^{33}$ & Clinical & $21 / 63(33)$ & $6 / 58(10)$ & $<0.01$ \\
\hline Raffetto et al ${ }^{34}$ & Clinical & $42 / 177(24)$ & $5 / 82(6.1)$ & 0.002 \\
\hline Golledge et al ${ }^{4}$ & Questionnaire & $266 / 873(31)$ & $2,883 / 1,0872(27)$ & 0.01 \\
\hline Henriksen et al ${ }^{35}$ & Clinical & $85 / 601(14)$ & $2,936 / 1,8331(16)$ & 0.632 \\
\hline Gindera et al ${ }^{36}$ & CT & $60 / 236(25.4)$ & $26 / 236(11)$ & $<0.001$ \\
\hline Müller et al ${ }^{10}$ & $\mathrm{CT}$ & $16 / 99(16.2)$ & $9 / 100(9)$ & 0.14 \\
\hline Current study & $\begin{array}{l}\text { Questionnaire (AAA), } \\
\text { CT (controls) }\end{array}$ & $48 / 195(25)$ & $9 / 100(9)$ & 0.001 \\
\hline
\end{tabular}

Abbreviations: AAA, abdominal aortic aneurysms; CT, computed tomography; MRI, magnetic resonance imaging; NS, not significant. ${ }^{a}$ The numbers indicate the number of patients with hernia/total number of patients examined in each group.

${ }^{b}$ Comparison of hernia prevalences between AAA cases and controls, $p$-values are taken directly from the original publications.

were evaluated for presence of hernia, and patients' clinical data were collected from the medical records as previously described. ${ }^{10}$

\section{Statistical Analyses}

First, we performed a univariate comparison of the AAA and control group. The mean, median, standard deviation (SD), maximum, and minimum values were calculated. For categorical variables we performed a cross tabulation. To measure the statistical significance, Mann-Whitney $U$-test, Chisquared $\left(x^{2}\right)$ test, and Fisher's exact test (as appropriate) were used.

The prevalences of inguinal and incisional hernias were estimated for each treatment group separately. Differences in prevalences of inguinal and incisional hernias among the four AAA patient groups were tested using $x^{2}$ test when the sample size for each cell in the analysis was $>5$ or Fisher's exact test when the sample size was $\leq 5$. Multivariate logistic regression was utilized to control for confounding variables of sex and age.

Age is reported in years at the time the questionnaire was administered (when information regarding the occurrence of a hernia was obtained). Statistical Analysis Software (SAS V.9.2 for Windows, SAS Institute Inc., Cary, NC) and SPSS statistical package (v22 for Windows, IBM, Armonk, NY) were used for analyses.

\section{Literature Search}

All studies which determined the incidence of inguinal hernias and/or incisional hernias in patients with AAA were identified using a two-step search strategy. First, a
PubMed search with keywords "aneurysm AND hernia" was performed for articles published between 1966 and May 2019. Second, relevant studies were identified by a manual search in the references of the identified articles.

\section{Results}

The AAA group consisted of 195 patients, with a mean age of $75.9( \pm 8.6)$ years. There was no significant difference in age among males $(n=178)$ and females $(n=17 ; p=0.08)$. The control group included 100 patients with a mean age of 71.2 $( \pm 8.6)$ years and was therefore significantly younger than the AAA group $(75.9 \pm 8.6 ; p<0.001)$. The mean age was $76.2 \pm 8.4$ years for the rAAA, $75.5 \pm 8.8$ years for the eAAA, $75.2 \pm 8.6$ years for EVAR, and $76.8 \pm 7.5$ years for the sAAA group. The mean sizes of the diameters of the AAAs were $5.8 \pm 1.1 \mathrm{~cm}$ for the eAAA, $5.8 \pm 0.8 \mathrm{~cm}$ for EVAR, and $4.2 \pm 0.5 \mathrm{~cm}$ for the sAAA group. Altogether $11(6 \%)$ of the 195 patients reported positive family history for AAA. Among the four subgroups, the number of AAA patients with positive family history varied from one (2\%) in the EVAR group to three (14\%) in the rAAA group.

Clinical data from the AAA and control patients are presented in - Table 3. AAA patients were more likely to suffer from hypertension, PAD, coronary artery disease (CAD), dyslipidemia and chronic obstructive pulmonary disease (COPD; all $p<0.001$ ), as well as to be ever smokers $(p<0.001)$. Treatment with medications (aspirin, nitrates, $\beta$ blockers, and statins) was significantly higher in the AAA group. AAA patients had significantly lower hemoglobin level and thrombocyte count but higher glucose and 
Table 2 Review of literature on association between incisional hernia and abdominal aortic aneurysms

\begin{tabular}{|c|c|c|c|c|}
\hline \multirow[t]{2}{*}{ Study } & \multirow[t]{2}{*}{ Examination method } & \multicolumn{2}{|c|}{ Incisional hernia ${ }^{a}$} & \multirow[t]{2}{*}{$p$-Value ${ }^{b}$} \\
\hline & & $\begin{array}{l}\text { AAA } \\
n(\%)\end{array}$ & $\begin{array}{l}\text { Controls (PAD) } \\
n(\%)\end{array}$ & \\
\hline Darke and Eadie ${ }^{37}$ & Clinical & $9 / 34(26)$ & & \\
\hline Stevick et al ${ }^{38}$ & Clinical & $10 / 27(37)$ & 4/39(10) & $<0.01$ \\
\hline Hall et $\mathrm{al}^{29}$ & Clinical & $13 / 128(10)$ & $2 / 65(3.0)$ & $<0.05$ \\
\hline Johnson et $\mathrm{al}^{39}$ & Clinical & $14 / 281(5.0)$ & - & - \\
\hline Holland et al ${ }^{40}$ & Clinical & 13/34 (38.2) & $6 / 30(20)$ & NA \\
\hline Adye and Luna ${ }^{30}$ & Clinical & $18 / 58(31)$ & $5 / 42(12)$ & 0.025 \\
\hline Johnson et al ${ }^{39}$ & Clinical & $26 / 265(9.8)$ & $10 / 331(3.0)$ & NA \\
\hline Musella et $\mathrm{al}^{32}$ & MRI & $16 / 51(32)$ & $11 / 63(17)$ & $<0.03$ \\
\hline Papadimitriou et $\mathrm{al}^{33}$ & Clinical & $7 / 63(11)$ & $2 / 58(3.4)$ & $<\mathbf{0 . 0 5}$ \\
\hline Raffetto et $\mathrm{al}^{34}$ & Clinical & $50 / 177(28)$ & $9 / 82(11)$ & 0.003 \\
\hline Liapis et $a^{41}$ & Clinical & $32 / 197(16)$ & $5 / 67(7.4)$ & 0.029 \\
\hline Rodriguez et al ${ }^{42}$ & $\mathrm{CT}$ & $14 / 61(23)$ & - & - \\
\hline Fassiadis et al ${ }^{43}$ & Clinical + US & 26/37 (79) & - & - \\
\hline Laohapensang et $\mathrm{al}^{24}$ & Clinical & $4 / 18(22)$ & - & - \\
\hline Panayiotopoulos et al ${ }^{44}$ & NA & $134 / 421(32)$ & - & - \\
\hline Bevis et al ${ }^{45}$ & Clinical + US & $16 / 43(37)$ & - & - \\
\hline Gruppo et al ${ }^{46}$ & Clinical & $51 / 412(12)$ & $73 / 653(11)$ & 0.62 \\
\hline Henriksen et $\mathrm{al}^{21}$ & Clinical & $108 / 1759(6.1)$ & $40 / 838(4.7)$ & 0.16 \\
\hline Wiegering et al ${ }^{47}$ & Clinical questionnaire & $10 / 72(13.9)$ & $7 / 27$ (25.9; colorectal surgery) & NS \\
\hline Current study & Questionnaire & 26/112 (23) & - & - \\
\hline
\end{tabular}

Abbreviations: AAA, abdominal aortic aneurysms; MRI, magnetic resonance imaging; NA, data not available; NS, not significant; PAD, peripheral arterial disease; US, ultrasonography

${ }^{a}$ The numbers indicate the number of patients with hernia/total number of patients examined in each group.

${ }^{\mathrm{b}}$ Comparison of hernia prevalence between AAA cases and controls, $p$-values are taken directly from the original publications.

creatinine level. In multivariate analysis, we found a significant association of AAA with hypertension, CAD, COPD, and ever smoking (-Table 4).

Clinical data for each AAA subgroup is presented in - Table 5. We looked at the age of the patients at two time points, at the initiation of the study and at the time of operation. Age did not differ significantly between the groups for either time point. Cardiovascular risk factors between the groups were not significantly different, with the exception of dyslipidemia, which was significantly lower in the rupture group. Treatment with medications (statins and $\beta$-blockers) was significantly lower in the ruptured AAA group. Preoperative laboratory measurements for $\mathrm{C}$-reactive protein were significantly higher in patients with ruptured AAA. A comparison of each AAA group with the control group did not reveal any substantial differences, as stated in - Table 6 .

A total of $48(25 \%)$ of the 195 AAA patients reported having had an inguinal hernia and 26 (23\%) of the 112 patients who had undergone an open repair (rAAA + eAAA) reported an incisional hernia ( - Table 7 ). Many of the patients with inguinal hernia $(32 / 48,67 \%)$ had had herniorrhaphy, increasing the likelihood that the diagnoses reported by the patients in the questionnaire were correct. The prevalence of inguinal hernia in the control group was significantly lower than in the AAA group $(9 / 100,9 \%$, $p=0.001$ ). An incisional hernia was found in 2 (2\%) of control patients. We compared the prevalences of hernias in the different treatment groups for AAA ( - Tables $\mathbf{7}$ and $\mathbf{8}$ ). The prevalences of inguinal and incisional hernias in the rAAA group of 22 patients were $9 \%$ (two patients) and 18\% (four patients), respectively. Herniorrhaphy was reported in one patient with an inguinal hernia and one patient with an incisional hernia. In the eAAA group, 22 of 90 (24\%) patients had inguinal hernia, $12(55 \%)$ of which had been repaired operatively. In addition, 22 of 90 (24\%) of the eAAA group patients reported incisional hernia, $11(50 \%)$ of which were surgically repaired. In the EVAR group, 15 (35\%) patients had inguinal hernias, $12(80 \%)$ of which had been surgically repaired. In the sAAA group, 9 of $40(23 \%)$ patients had a history of inguinal hernias, 7 (78\%) of whom reported having had a herniorrhaphy.

Comparisons between males and females for family history of AAA ( $p=0.79$; odds ratio $[\mathrm{OR}]=0.84 ; 95 \%$ confidence interval $[\mathrm{CI}]: 0.10-7.11)$, incisional $(p=0.24 ; \mathrm{OR}=3.0 ; 95 \%$ CI: $0.38-23.44)$, or inguinal hernias $(p=0.16$; $\mathrm{OR}=2.61 ; 95 \%$ 
Table 3 Characteristics of the abdominal aortic aneurysms and control groups

\begin{tabular}{|c|c|c|c|}
\hline Variable & $\begin{array}{l}\text { AAA group } \\
n=195\end{array}$ & $\begin{array}{l}\text { Control group } \\
n=100\end{array}$ & p-Value \\
\hline $\begin{array}{l}\text { Age }(y) \text { at time of study } \\
\text { Mean } \pm S D\end{array}$ & $75.9 \pm 8.6$ & $71.2 \pm 8.6$ & $<0.001$ \\
\hline Males (\%) & 91.3 & 79.0 & 0.005 \\
\hline $\begin{array}{l}\text { Height }(\mathrm{cm}) \\
\text { Mean } \pm \text { SD }\end{array}$ & $171.9 \pm 15.4$ & $174.0 \pm 8.1$ & 0.245 \\
\hline $\begin{array}{l}\text { Weight }(\mathrm{kg}) \\
\text { Mean } \pm \text { SD }\end{array}$ & $79.1 \pm 14.2$ & $79.5 \pm 13.9$ & 0.429 \\
\hline $\begin{array}{l}\text { Hemoglobin }(\mathrm{mmol} / \mathrm{L}) \\
\text { Mean } \pm \text { SD }\end{array}$ & $8.4 \pm 1.2$ & $14.5 \pm 11.9$ & $<0.001$ \\
\hline $\begin{array}{l}\text { White blood cell count }\left(\times 10^{9} / \mathrm{L}\right) \\
\text { Mean } \pm \text { SD }\end{array}$ & $7.9 \pm 3.4$ & $8.7 \pm 6.1$ & 0.644 \\
\hline $\begin{array}{l}\text { Thrombocyte count }\left(\times 10^{9} / \mathrm{L}\right) \\
\text { Mean } \pm \text { SD }\end{array}$ & $221.7 \pm 64.7$ & $253.5 \pm 94.9$ & 0.010 \\
\hline $\begin{array}{l}\text { Glucose } \\
\text { Mean } \pm \text { SD }\end{array}$ & $6.7 \pm 2.2$ & $6.2 \pm 2.4$ & 0.015 \\
\hline $\begin{array}{l}\text { C-reactive protein }(\mathrm{mg} / \mathrm{L}) \\
\text { Mean } \pm \text { SD }\end{array}$ & $21.9 \pm 41.1$ & $29.3 \pm 54.1$ & 0.337 \\
\hline $\begin{array}{l}\text { Cholesterol }(\mathrm{mmol} / \mathrm{L}) \\
\text { Mean } \pm \mathrm{SD}\end{array}$ & $5.3 \pm 1.4$ & $5.5 \pm 0.8$ & 0.581 \\
\hline $\begin{array}{l}\mathrm{LDL}(\mathrm{mmol} / \mathrm{L}) \\
\text { Mean } \pm \mathrm{SD}\end{array}$ & $3.5 \pm 1.3$ & $3.7 \pm 0.6$ & 0.631 \\
\hline $\begin{array}{l}\mathrm{HDL}(\mathrm{mmol} / \mathrm{L}) \\
\text { Mean } \pm \mathrm{SD}\end{array}$ & $1.2 \pm 0.6$ & $1.1 \pm 0.2$ & 0.815 \\
\hline $\begin{array}{l}\text { Triglycerides }(\mathrm{mmol} / \mathrm{L}) \\
\text { Mean } \pm \text { SD }\end{array}$ & $1.8 \pm 0.6$ & $2.2 \pm 0.7$ & 0.106 \\
\hline $\begin{array}{l}\text { Creatinine }(\mathrm{mmol} / \mathrm{L}) \\
\text { Mean } \pm \mathrm{SD}\end{array}$ & $111.8 \pm 83.3$ & $91.9 \pm 34.2$ & $<0.001$ \\
\hline Hypertension $^{\mathrm{a}}(\%)$ & 97.8 & 70.0 & $<0.001$ \\
\hline Peripheral arterial disease (\%) & 28.3 & 8.1 & $<0.001$ \\
\hline Coronary artery disease (\%) & 58.6 & 19.0 & $<0.001$ \\
\hline Myocardial infarction (\%) & 25.4 & 14.0 & 0.33 \\
\hline Diabetes mellitus (\%) & 22.1 & 20.4 & 0.879 \\
\hline Dyslipidemiab $^{\mathrm{b}} \%$ ) & 61.5 & 34.7 & $<0.001$ \\
\hline COPD (\%) & 28.0 & 4.0 & $<0.001$ \\
\hline Ever smoke (\%) & 77.2 & 52.9 & $<0.001$ \\
\hline Aspirin (\%) & 75.7 & 27.4 & $<0.001$ \\
\hline Clopidogrel (\%) & 5.7 & 7.4 & 0.606 \\
\hline Coumadin (\%) & 13.1 & 7.4 & 0.223 \\
\hline Nitrates (\%) & 17.7 & 6.3 & 0.009 \\
\hline Calcium antagonists (\%) & 27.3 & 17.9 & 0.101 \\
\hline ACE inhibitors (\%) & 47.7 & 38.9 & 0.200 \\
\hline Beta-blockers (\%) & 60.8 & 46.3 & 0.029 \\
\hline Statins (\%) & 51.4 & 34.7 & 0.010 \\
\hline
\end{tabular}

Abbreviations: AAA, abdominal aortic aneurysms; ACE, angiotensin converting enzyme; COPD, chronic obstructive pulmonary disease; HDL, highdensity lipoprotein; LDL, low-density lipoprotein; SD, standard deviation.

Note: Laboratory results are shown as mean \pm SD and were measured preoperatively for AAA or at the time of the computed tomography angiography examination for the control group.

BBlood pressure $\geq 140 / 90 \mathrm{~mm} \mathrm{Hg}$.

bIncreased LDL (male and female: $\geq 4.12 \mathrm{mmol} / \mathrm{L}$; age $>35$ years) and decreased $\mathrm{HDL}$ (male: $\leq 0.90 \mathrm{mmol} / \mathrm{l}$; female $\leq 1.3 \mathrm{mmol} / \mathrm{L}$; age $>35$ years). 
14 Hernias and Abdominal Aortic Aneurysms Hinterseher et al.

Table 4 Results of the multivariate analysis between the abdominal aortic aneurysms and control patients

\begin{tabular}{|l|l|l|}
\hline Variable & OR $(95 \% \mathrm{CI})$ & $p$-Value \\
\hline Hypertension & $8.13(2.25-29.41)$ & $\mathbf{0 . 0 0 1}$ \\
\hline Coronary artery disease & $3.71(1.89-7.29)$ & $<\mathbf{0 . 0 0 1}$ \\
\hline COPD & $6.82(1.95-23.85)$ & $\mathbf{0 . 0 0 3}$ \\
\hline Ever smoke & $2.55(1.31-4.95)$ & 0.006 \\
\hline Peripheral arterial disease & $1.82(0.68-4.84)$ & 0.232 \\
\hline Dyslipidemia & $1.43(0.73-2.81)$ & 0.297 \\
\hline
\end{tabular}

Abbreviations: $\mathrm{Cl}$, confidence interval; COPD, chronic obstructive pulmonary disease; OR, odds ratio.
CI: 0.57-11.87) were tested with univariate analysis and were not statistically significant. Only one female patient had an incisional hernia, and only two females had inguinal hernias, which could explain the lack of significance, as well as the wide CIs. To determine if the female patients were influencing the statistical outcomes, we ran additional analyses on the male patients only. The results were similar to those of the entire group and are included here. When all four groups were compared for the prevalence of inguinal hernias in univariate analysis, there was no significant difference between the groups ( $p=0.15$ for the entire sample, and $p=0.21$ for males only).

Prevalence of inguinal hernias did not differ $(p=0.15$; $\mathrm{OR}=3.2 ; 95 \% \mathrm{CI}: 0.7-14.96$ for the entire sample, and

Table 5 Characteristics of the abdominal aortic aneurysms groups

\begin{tabular}{|c|c|c|c|c|c|}
\hline Variable & $\begin{array}{l}\text { rAAA (open) } \\
(n=21)\end{array}$ & $\begin{array}{l}\text { eAAA (open) } \\
(n=90)\end{array}$ & $\begin{array}{l}\text { EVAR } \\
(n=42)\end{array}$ & $\begin{array}{l}\text { SAAA } \\
(n=39)\end{array}$ & $p$-Value \\
\hline $\begin{array}{l}\text { Age (y) at time of study } \\
\text { Mean } \pm \text { SD }\end{array}$ & $76.2 \pm 8.4$ & $75.5 \pm 8.8$ & $75.2 \pm 8.6$ & $76.8 \pm 7.5$ & 0.83 \\
\hline $\begin{array}{l}\text { Age }(y) \text { at operation } \\
\text { Mean } \pm \text { SD }\end{array}$ & $70.2 \pm 8.2$ & $68.4 \pm 8.7$ & $71.1 \pm 9.0$ & $\mathrm{~N} / \mathrm{A}$ & 0.12 \\
\hline Males (\%) & 85.7 & 91.1 & 97.6 & 87.2 & 0.22 \\
\hline Height $(\mathrm{cm})$ & $169.9 \pm 9.1$ & $171.0 \pm 20.4$ & $173.5 \pm 6.3$ & $175.3 \pm 7.3$ & 0.16 \\
\hline Weight $(\mathrm{kg})$ & $72.6 \pm 12.5$ & $79.4 \pm 16.3$ & $80.2 \pm 10.8$ & $81.9 \pm 11.8$ & 0.07 \\
\hline $\begin{array}{l}\text { Hemoglobin }(\mathrm{mmol} / \mathrm{L}) \\
\text { Mean } \pm \text { SD }\end{array}$ & $7.5 \pm 1.4$ & $8.5 \pm 0.5$ & $8.6 \pm 1.0$ & $8.5 \pm 0.9$ & $<0.01$ \\
\hline $\begin{array}{l}\text { White blood cell count }\left(\times 10^{9} / \mathrm{L}\right) \\
\text { Mean } \pm \text { SD }\end{array}$ & $9.9 \pm 3.0$ & $7.2 \pm 1.8$ & $7.4 \pm 1.7$ & $10.3 \pm 8.8$ & $<0.01$ \\
\hline $\begin{array}{l}\text { Thrombocyte count }\left(\times 10^{9} / \mathrm{L}\right) \\
\text { Mean } \pm \text { SD }\end{array}$ & $221.7 \pm 87.1$ & $223.9 \pm 61.1$ & $219.4 \pm 67.0$ & $214.8 \pm 39.2$ & 0.96 \\
\hline $\begin{array}{l}\text { Glucose } \\
\text { Mean } \pm \text { SD }\end{array}$ & $7.8 \pm 3.2$ & $6.3 \pm 1.7$ & $6.6 \pm 2.0$ & $7.4 \pm 3.6$ & 0.06 \\
\hline C-reactive protein (mg/L) & $94.8 \pm 63.5$ & $9.3 \pm 16.3$ & $10.9 \pm 16.8$ & $6.6 \pm 9.4$ & $<0.01$ \\
\hline $\begin{array}{l}\text { Cholesterol }(\mathrm{mmol} / \mathrm{L}) \\
\text { Mean } \pm \text { SD }\end{array}$ & $4.8 \pm 1.5$ & $5.5 \pm 1.3$ & $5.2 \pm 1.4$ & $4.8 \pm 1.5$ & 0.28 \\
\hline $\begin{array}{l}\mathrm{LDL}(\mathrm{mmol} / \mathrm{L}) \\
\text { Mean } \pm \mathrm{SD}\end{array}$ & $3.4 \pm 2.0$ & $3.7 \pm 1.3$ & $3.5 \pm 1.1$ & $3.5 \pm 1.0$ & 0.76 \\
\hline $\begin{array}{l}\mathrm{HDL}(\mathrm{mmol} / \mathrm{L}) \\
\text { Mean } \pm \mathrm{SD}\end{array}$ & $0.9 \pm 0.4$ & $1.2 \pm 0.6$ & $1.6 \pm 10.7$ & $1.2 \pm 0.4$ & 0.28 \\
\hline $\begin{array}{l}\text { Triglycerides }(\mathrm{mmol} / \mathrm{L}) \\
\text { Mean } \pm \text { SD }\end{array}$ & $1.8 \pm 0.7$ & $1.7 \pm 0.6$ & $1.9 \pm 1.4$ & $1.8 \pm 0.9$ & 0.84 \\
\hline $\begin{array}{l}\text { Creatinine }(\mathrm{mmol} / \mathrm{L}) \\
\text { Mean } \pm \mathrm{SD}\end{array}$ & $100.7 \pm 27.1$ & $114.4 \pm 107.0$ & $105.7 \pm 33.8$ & $129.0 \pm 78.5$ & 0.74 \\
\hline $\begin{array}{l}\text { Diameter }(\mathrm{cm}) \\
\text { Mean } \pm \text { SD }\end{array}$ & NA & $5.8 \pm 1.1$ & $5.8 \pm 0.8$ & $4.2 \pm 0.5$ & $<0.01$ \\
\hline Hypertension $^{\mathrm{a}}(\%)$ & 95.2 & 96.5 & 100 & 100.0 & 0.36 \\
\hline Peripheral arterial disease (\%) & 42.9 & 27.9 & 22.0 & 28.1 & 0.39 \\
\hline Coronary artery disease (\%) & 47.6 & 53.5 & 73.8 & 59.4 & 0.11 \\
\hline Myocardial infarction (\%) & 14.3 & 24.1 & 29.3 & 30.3 & 0.54 \\
\hline Diabetes mellitus (\%) & 23.8 & 18.6 & 26.8 & 23.8 & 0.73 \\
\hline Dyslipidemiab $(\%)^{\text {b }}$ & 33.3 & 59.6 & 68.3 & 77.4 & 0.01 \\
\hline COPD (\%) & 23.8 & 28.2 & 26.8 & 28.6 & 0.98 \\
\hline
\end{tabular}


Table 5 (Continued)

\begin{tabular}{|l|l|l|l|l|l|}
\hline Variable & $\begin{array}{l}\text { rAAA (open) } \\
(\boldsymbol{n = 2 1})\end{array}$ & $\begin{array}{l}\text { eAAA (open) } \\
(\boldsymbol{n = 9 0 )}\end{array}$ & $\begin{array}{l}\text { EVAR } \\
(\boldsymbol{n}=\mathbf{4 2})\end{array}$ & $\begin{array}{l}\text { SAAA } \\
(\boldsymbol{n}=\mathbf{3 9})\end{array}$ & $\boldsymbol{p}$-Value \\
\hline Ever smoke (\%) & 80.0 & 70.2 & 90.0 & 86.4 & 0.07 \\
\hline Family History (\%) & 14.3 & 5.8 & 2.4 & 5.6 & 0.35 \\
\hline Cancer (\%) & 21 & 17.7 & 21.6 & 35.7 & 0.36 \\
\hline Aspirin (\%) & 75 & 74.7 & 82.5 & 70.6 & 0.67 \\
\hline Clopidogrel (\%) & 0.0 & 6.2 & 4.9 & 8.8 & 0.72 \\
\hline Coumadin (\%) & 25.0 & 7.4 & 12.2 & 20.6 & 0.07 \\
\hline Nitrates (\%) & 20.0 & 22.2 & 12.5 & 11.8 & 0.44 \\
\hline Calcium antagonists (\%) & 15.0 & 34.6 & 26.8 & 17.7 & 0.16 \\
\hline ACE inhibitors (\%) & 30.0 & 42.0 & 56.1 & 58.8 & 0.10 \\
\hline Beta-blockers (\%) & 50.0 & 51.9 & 68.3 & 76.5 & 0.05 \\
\hline Statins (\%) & 25.0 & 47.8 & 56.1 & 67.7 & $\mathbf{0 . 0 2}$ \\
\hline
\end{tabular}

Abbreviations: AAA, abdominal aortic aneurysms; ACE, angiotensin converting enzyme; COPD, chronic obstructive pulmonary disease; EVAR, AAA with elective endovascular repair; HDL, high-density lipoprotein; LDL, low-density lipoprotein; NA, data not available; rAAA, ruptured AAA with open repair; eAAA, AAA with elective open repair; sAAA, small AAA under surveillance; SD, standard deviation.

Note: Laboratory results are shown as mean \pm SD and were measured preoperatively.

${ }^{\mathrm{a} B l o o d}$ pressure $\geq 140 / 90 \mathrm{~mm} \mathrm{Hg}$.

bIncreased LDL (male and female: $\geq 4.12 \mathrm{mmol} / \mathrm{L}$; age $>35$ years) and decreased HDL (male: $\leq 0.90 \mathrm{mmol} / \mathrm{L}$; female $\leq 1.3 \mathrm{mmol} / \mathrm{L}$; age $>35$ years).

$p=0.23 ; \mathrm{OR}=2.7 ; 95 \% \mathrm{CI}: 0.6-12.91$ for males only) between the two open surgery groups, rAAA and eAAA, nor was there a difference when comparing all three procedures (rAAA, eAAA, or EVAR) to surveillance ( $\mathrm{sAAA} ; p=0.73 ; \mathrm{OR}=0.86$; 95\% CI: $0.38-2.0$ for the entire sample, and $p=0.98$; OR $=0.99 ; 95 \% \mathrm{CI}$ : $0.43-2.3$ for males only).

No difference ( $p=0.21$ for the entire sample, and $p=0.22$ for males only) in the prevalence of inguinal hernias existed between those patient groups which had open surgery (rAAA and eAAA) compared with those with a minimally invasive procedure (EVAR) or surveillance (sAAA).

All groups were then compared using multivariate analysis, controlling for the probable confounding factors of age and sex (-Table 8). For the prevalence of inguinal hernia, the comparison of all AAA patients versus control patients was highly significant ( $p=0.006$; $\mathrm{OR}=4.00 ; 95 \% \mathrm{CI}: 1.49-10.66$ ), while EVAR versus rAAA was borderline significant $(p=0.04$; $\mathrm{OR}=5.1 ; 95 \% \mathrm{CI}: 1.01-25.3)$. The other groups were not statistically different from each other.

Only the surgical groups (rAAA compared with eAAA) were analyzed for incisional hernias, and no significant difference was found ( $p=0.39$ ).

\section{Discussion}

Our study demonstrated a higher prevalence of inguinal hernia in AAA patients compared with the control group and a significant association between hernia and AAA in a multivariate analysis. The prevalence of inguinal hernia did not, however, differ between the AAA subgroups, suggesting that hernias do not contribute to increased severity of the aneurysmal disease.
Patients diagnosed with known connective tissue disorders such as the Marfan syndrome (OMIM ID: 154700), the Loeys-Dietz syndrome (OMIM IDs: 609192, 613795, 608967, 610380,614816 , and 610168), and the Ehlers-Danlos vascular type (OMIM ID: 130050) are prone to aortic aneurysms and dissections, as well as to rupture of other hollow organs such as uterus and bowel (http://omim.org). They are also more susceptible to inguinal and incisional hernias. These patients have mutations in genes of the structural proteins of the connective tissues, that is, fibrillin I (FBN1) in the Marfan syndrome, in the SMAD3, TGFB2, and TGFB-receptor genes (TGFBR1 and TGFBR2) in the syndromic forms of thoracic aortic aneurysms, and in Type III collagen gene (COL3A1) in the case of Ehlers-Danlos syndrome Type IV, also known as the vascular type of the Ehlers-Danlos syndrome.

It is possible that more common nonsyndromic diseases, such as AAAs also involve a connective tissue defect ${ }^{3}$ which increases the patient's risk for abdominal wall hernias. Although AAA and abdominal wall hernias present common risk factors (e.g., smoking), there seems to be an independent association of these two diseases. ${ }^{3,5}$ Clinical observations show that abdominal wall hernias are more common in AAA patients than in the general population. ${ }^{9}$ Furthermore, pathobiological studies on abdominal wall hernias revealed similarities to the pathogenesis of AAA. ${ }^{11-15}$

Several studies have investigated the expression of proteases responsible for degradation of the extracellular matrix (ECM). Matrix metalloproteinase 1 (MMP1) expression was increased in scar tissue of the skin from patients with incisional hernia and recurrent inguinal hernias, ${ }^{14}$ but not in patients with primary inguinal hernia. ${ }^{14}$ Similarly, elevated levels of MMP1 have been detected in patients with AAA. ${ }^{15}$ 
Table 6 Comparison of each AAA group with the control group

\begin{tabular}{|c|c|c|c|c|}
\hline Variable & $\begin{array}{l}\text { rAAA versus } \\
\text { control group } \\
p \text {-Value }(n=21)\end{array}$ & $\begin{array}{l}\text { eAAA versus } \\
\text { control group } \\
p \text {-Value }(n=90)\end{array}$ & $\begin{array}{l}\text { EVAR versus } \\
\text { control group } \\
p \text {-Value }(n=42)\end{array}$ & $\begin{array}{l}\text { sAAA versus } \\
\text { control group } \\
p \text {-Value }(n=39)\end{array}$ \\
\hline $\begin{array}{l}\text { Age }(y) \text { at time of study } \\
\text { Mean } \pm \text { SD }\end{array}$ & 0.012 & $<0.001$ & $<0.001$ & 0.002 \\
\hline Males (\%) & 0.561 & 0.026 & 0.337 & 0.004 \\
\hline Height (cm) & 0.099 & 0.267 & 0.670 & 0.551 \\
\hline Weight (kg) & 0.061 & 0.343 & 0.238 & 0.293 \\
\hline Hemoglobin (mmol/L) & $<0.001$ & $<0.001$ & $<0.001$ & $<0.001$ \\
\hline White blood cell count $\left(\times 10^{9} / \mathrm{L}\right)$ & 0.004 & 0.379 & 0.194 & 0.968 \\
\hline Thrombocyte count $\left(\times 10^{9} / \mathrm{L}\right)$ & 0.182 & 0.025 & 0.184 & 0.050 \\
\hline Glucose & 0.003 & 0.104 & 0.231 & 0.123 \\
\hline C-reactive protein (mg/L) & $<0.001$ & 0.008 & 0.368 & 0.276 \\
\hline Cholesterol (mmol/L) & 0.515 & 0.888 & 0.140 & 0.534 \\
\hline $\mathrm{LDL}(\mathrm{mmol} / \mathrm{L})$ & 0.630 & 0.801 & 0.237 & 0.867 \\
\hline $\mathrm{HDL}(\mathrm{mmol} / \mathrm{L})$ & 0.521 & 0.906 & 0.929 & 0.135 \\
\hline Triglycerides (mmol/L) & 0.264 & 0.093 & 0.333 & 0.181 \\
\hline Creatinine (mmol/L) & 0.075 & $<0.001$ & 0.004 & 0.009 \\
\hline Hypertension (\%) & 0.014 & $<0.001$ & $<0.001$ & $<0.001$ \\
\hline Peripheral arterial disease (\%) & $<0.001$ & $<0.001$ & 0.006 & 0.043 \\
\hline Coronary artery disease (\%) & 0.010 & $<0.001$ & $<0.001$ & $<0.001$ \\
\hline Myocardial infarction (\%) & 1.000 & 0.090 & 0.064 & 0.054 \\
\hline Diabetes mellitus (\%) & 0.770 & 0.853 & 0.631 & 0.503 \\
\hline Dyslipidemia (\%) & 1.000 & 0.001 & $<0.001$ & $<0.001$ \\
\hline COPD (\%) & 0.008 & $<0.001$ & 0.001 & $<0.001$ \\
\hline Ever smoke (\%) & 0.043 & 0.044 & 0.006 & $<0.001$ \\
\hline Aspirin (\%) & $<0.001$ & $<0.001$ & $<0.001$ & $<0.001$ \\
\hline Clopidogrel (\%) & 0.603 & 1.000 & 0.723 & 0.723 \\
\hline Coumadin (\%) & 0.034 & 1.000 & 0.051 & 0.347 \\
\hline Nitrates (\%) & 0.070 & 0.003 & 0.454 & 0.301 \\
\hline Calcium antagonists (\%) & 1.000 & 0.015 & 1.000 & 0.254 \\
\hline ACE inhibitors (\%) & 0.612 & 0.645 & 0.069 & 0.090 \\
\hline Beta-blockers (\%) & 0.809 & 0.450 & 0.003 & 0.024 \\
\hline Statins (\%) & 0.447 & 0.066 & 0.001 & 0.024 \\
\hline
\end{tabular}

Abbreviations: AAA, abdominal aortic aneurysms; ACE, angiotensin converting enzyme; COPD, chronic obstructive pulmonary disease; EVAR, AAA with elective endovascular repair; HDL, high-density lipoprotein; LDL, low-density lipoprotein; rAAA, ruptured AAA with open repair; eAAA, AAA with elective open repair; sAAA, small AAA under surveillance; SD, standard deviation.

Also, fibroblast cultures from the abdominal skin in direct inguinal hernia patients showed an increased matrix metalloproteinase 2 (MMP2) expression, ${ }^{13}$ MMP2 mRNA levels were increased in incisional hernia samples, ${ }^{14}$ and in serum of AAA patients. ${ }^{15}$

The expression of metalloproteinase inhibitor 2 (TIMP2), one of the naturally occurring inhibitors of MMPs, was decreased in abdominal skin of hernia patients, ${ }^{13}$ in fascia transversalis specimens of inguinal hernia patients, ${ }^{11}$ and in the aneurysmal aortic wall. ${ }^{15}$ These findings suggest an imbalance between the proteolytic activity of MMPs and their inhibitors in the abdominal skin prone to hernia formation and in the aortic wall with aneurysmal dilatation.

It is also plausible that hernias and AAAs develop due to defects in the structural proteins of skin, fascia, and aorta. The ratio of Type I to III collagen was shown to be reduced in skin fibroblasts, fascia transversalis, and the hernial sac in patients with inguinal and incisional hernia. ${ }^{12,14}$ Collagens, which are 
Table 7 Prevalences of different types of hernias of the abdominal wall among abdominal aortic aneurysms patients in the vascular center of the University Hospital Carl Gustav Carus, Technical University of Dresden, Germany

\begin{tabular}{|c|c|c|c|c|}
\hline Group & $\begin{array}{l}\text { AAA patients, } n(\%) \\
\text { total number } \\
n(\%)\end{array}$ & $\begin{array}{l}\text { AAA patients, } n(\%) \\
\text { with incisional hernia } \\
\text { after AAA surgery } \\
n(\%)\end{array}$ & $\begin{array}{l}\text { AAA patients, } n(\%) \text { with } \\
\text { incisional hernia after } \\
\text { other surgeries } \\
n(\%)\end{array}$ & $\begin{array}{l}\text { AAA patients, } n(\%) \text { with } \\
\text { inguinal hernia } \\
n(\%)\end{array}$ \\
\hline \multicolumn{5}{|l|}{ IAAA: } \\
\hline All & 22 & $4(18)$ & $1(4.6)$ & $2(9.1)$ \\
\hline Male & $19(86)$ & $4(21)$ & $1(5.3)$ & $2(10.5)$ \\
\hline Female & $3(14)$ & 0 & 0 & 0 \\
\hline \multicolumn{5}{|l|}{ eAAA: } \\
\hline All & 90 & $22(24)$ & $5(6.8)$ & $22(24)$ \\
\hline Male & $82(91)$ & $21(25)$ & $4(5.5)$ & $21(25)$ \\
\hline Female & $8(8.9)$ & 1 & $1(17)$ & $1(13)$ \\
\hline \multicolumn{5}{|l|}{ EVAR: } \\
\hline All & 43 & & $3(7.0)$ & $15(35)$ \\
\hline Male & $42(98)$ & & $3(7.1)$ & $15(36)$ \\
\hline Female & $1(2.3)$ & & 0 & 0 \\
\hline \multicolumn{5}{|l|}{ SAAA: } \\
\hline All & 40 & & $2(5.0)$ & $9(23)$ \\
\hline Male & $35(88)$ & & $2(5.7)$ & $9(26)$ \\
\hline Female & $5(13)$ & & 0 & 0 \\
\hline \multicolumn{5}{|c|}{ All AAA cases: } \\
\hline All & 195 & $26(23)$ & $11(5.6)$ & $48(25)$ \\
\hline Male & $178(91)$ & $25(13)$ & $10(5.6)$ & $47(26)$ \\
\hline Female & $17(9)$ & $1(0.005)$ & $1(5.9)$ & $1(5.9)$ \\
\hline \multicolumn{5}{|c|}{ Control group: } \\
\hline All & 100 & & $2(2)$ & $9(9)$ \\
\hline Male & $79(79)$ & & $1(1)$ & $6(6)$ \\
\hline Female & $21(21)$ & & $1(1)$ & $3(3)$ \\
\hline
\end{tabular}

Abbreviations: AAA, abdominal aortic aneurysms; EVAR, AAA with endovascular repair; rAAA, ruptured AAA; eAAA, AAA with elective open repair; sAAA, small AAA under surveillance.

Table 8 Comparison of different abdominal aortic aneurysms treatment groups for the presence of inguinal and incisional hernias

\begin{tabular}{|l|l|l|l|}
\hline Hernia type & Comparison of AAA and control groups & $p$-Value & OR (95\% CI) \\
\hline Inguinal & EVAR versus rAAA & 0.040 & $5.1(1.01-25.3)$ \\
\hline & SAAA versus rAAA & 0.840 & $2.73(0.52-14.3)$ \\
\hline & eAAA versus rAAA & 0.560 & $3.02(0.64-14.24)$ \\
\hline & sAAA versus procedure (rAAA +eAAA + EVAR) & 0.730 & $0.86(0.37-2.0)$ \\
\hline & EVAR versus open repair (rAAA+eAAA) & 0.110 & $1.96(0.87-4.37)$ \\
\hline & SAAA versus open repair (rAAA +eAAA) & 0.530 & $1.06(0.34-2.56)$ \\
\hline Incisional & All AAA versus control & 0.006 & $4.00(1.49-10.66)$ \\
\hline
\end{tabular}

Abbreviations: AAA, abdominal aortic aneurysms; $\mathrm{Cl}$, confidence interval; EVAR, AAA with endovascular repair; OR, odds ratio; rAAA, ruptured AAA; eAAA, AAA with elective open repair; sAAA, small AAA under surveillance.

aStatistical analysis was performed with multivariate logistic regression adjusted for sex and age. 
major structural components of the ECM in the aorta and provide support and strength to the aorta, have also been shown to play a role in AAA development and rupture. ${ }^{3}$

In conclusion, the results summarized above provide strong evidence for the hypothesis that similar pathobiological mechanisms are involved in hernias and AAA. Consistent with this hypothesis are findings of two recently published studies. One of them detected an increased prevalence of AAA among 235 patients with inguinal hernia who were $>55$ years old compared with a control group of 203 patients without inguinal hernias. ${ }^{16}$ Another group of investigators found an increased prevalence of abdominal wall hernia in 110 patients with AAA (45\%) in comparison with 60 patients with AOD (5\%), disease that shares many of the same risk factors ( $p$-value $<0,001) .{ }^{17}$ Three other studies with fewer patients, however, showed contradictory results. ${ }^{7,18,19}$

It has also been suggested that surgical operations increase the patient's risk for hernia formation. One study detected higher prevalence of inguinal hernias after appendectomies and suggested changes in the muscle strength of the abdominal wall after transperitoneal operation. ${ }^{20}$ In our study, the prevalence of hernias was not increased among patients who had been operated using midline incision compared with AAA patients who were under surveillance. Moreover, a Danish nationwide retrospective study found that AAA is an independent risk factor for incisional hernia repair in patients undergoing open elective aortic reconstructive surgery. Patients undergoing AAA repair have a 1.6-fold higher risk of a subsequent hernia repair than patients undergoing AOD repair. ${ }^{21}$

Several previous studies showed a high prevalence of inguinal and incisional hernias among AAA patients ( - Tables 1 and $\mathbf{2}$ ). A total of 12 studies, 11 of which presented a comparison between AAA and control groups, have been published on the prevalence of inguinal hernias. In 8 of 11 of these studies, the prevalence of inguinal hernias among AAA patients was significantly higher than in the control group, and ranged between 19 and $41 \%$ (-Table 1 ). In three of the studies ( - Table 1 ), the prevalence of inguinal hernia was 14 , 16 and $22 \%$ in the AAA group compared to 16,9 , and $17 \%$ in the control group, respectively. Only two previous studies investigated the prevalence of abdominal wall hernias in patients with large and small AAA (AAA $<55$ vs. AAA $>55$ $\mathrm{mm})$. While Gindera et al ${ }^{35}$ demonstrated a lack of association between the two diseases, which confirms the finding of our study, Pitoulias et $\mathrm{al}^{17}$ found a significantly higher prevalence of hernia in large aneurysms (50 vs. $29.2 \%$, $p=0.03$ ). A recent study investigated the prevalence of AAA in patients with inguinal hernias and demonstrated a $27.7 \%$ prevalence of AAA among the study group. ${ }^{22}$

The prevalence of incisional hernias has been reported in 19 studies, 12 of which presented a comparison between AAA and control groups (-Table 2). Only 7 of 12 studies found a significant difference in the prevalence of incisional hernias between AAA (range: 10-37\%) and control (range: 3-26\%) groups (- Table 2 ).

It is possible to minimize the risk for incisional hernia by surgical techniques, such as using a nonabsorbable or slowly absorbable material, ${ }^{8}$ or prophylactic preperitoneal mesh placement after an open AAA repair. ${ }^{5,8}$ Results with a retroperitoneal approach in AAA repair were inconsistent. $^{23,24}$ A meta-analysis published in 2007 described a 2.8-fold higher risk for incisional hernias (after midline transperitoneal approach) and 2.9-fold higher risk for inguinal hernias in patients with AAA. ${ }^{6}$ The mean prevalence for inguinal and incisional hernias was 25 and 21\%, respectively. ${ }^{6}$ While the current study was in progress, Antoniou et $\mathrm{al}^{5}$ and Takagi and Umemoto ${ }^{25}$ repeated the meta-analysis, both with similar results.

\section{Limitations}

One limitation of the current study is that we obtained information about hernias by a questionnaire sent to the AAA patients. It is well known that mailed questionnaires have potential biases, since it is not clear if the answers are based on a proper clinical evaluation, or patient's self-perception. Furthermore, physical examination of hernias is known to have a relatively poor diagnostic accuracy. ${ }^{26}$ In the current study, information about herniorrhaphies performed in the past was also collected. Most of the patients who reported having inguinal hernias (67\%), had had herniorrhaphy, suggesting that the information can be considered reliable and is not based on only patient's self-perception or physical examination. Despite the differences in the study designs, our results agree with the previous studies (25\% for inguinal hernias and $23 \%$ for incisional hernias). Furthermore, another study, which also used a questionnaire, found that $31 \%$ of AAA patients had inguinal hernias, ${ }^{4}$ a prevalence very similar to ours. Further, the prevalence of inguinal hernias in our control group was relatively low (9\%) when compared with previous studies (5-27\%).

Another limitation of the study is that the response rate of sAAA patients was lower $(51 \%)$ than that of patients in the other groups (85-92\%) who underwent operations. This could have influenced the results, since it is possible that patients with existing hernias were more motivated to answer the questionnaire than the ones without hernias. The results presented here should be considered preliminary, since the sample sizes of the study groups were small. Further, stratifying the severity of AAA disease by therapy type (rAAAvs. EVAR vs. eAAA vs. SAAA) might not be as accurate as exact measurements of the AAA size or stress mapping of the aneurysm wall tension. However, this approach gives a general idea of the disease severity without the need of further, sometimes complicated and time-consuming measurements, and can therefore be easily undertaken in clinical practice. Finally, approximately half of the patients with ruptured AAA died perioperatively and could not be studied here.

\section{Conclusions}

In conclusion, our study confirms previous observations that patients with AAA have a relatively high prevalence of hernias and showed that the prevalence of hernias among AAA patients was not correlated with the size or rupture risk of AAA. Furthermore, prevalence of hernias was not increased among patients who had been operated compared with AAA patients who were under surveillance suggesting 
that surgical repair operation is not responsible for the increased hernia prevalence among AAA patients. These results suggest that the occurrence of hernias is not associated with a more aggressive AAA disease.

Funding

None.

\section{Conflict of Interest}

The authors declare no conflict of interest related to this article.

\section{Acknowledgments}

The authors would like to acknowledge support from the German Research Foundation (DFG) and the Open Access Publication Funds of Charité - Universitätsmedizin, Berlin.

\section{References}

1 Go AS, Mozaffarian D, Roger VLAmerican Heart Association Statistics Committee and Stroke Statistics Subcommittee. et al; Heart disease and stroke statistics-2014 update: a report from the American Heart Association. Circulation 2014;129(03):e28-e292

2 Cowan JA Jr., Dimick JB, Henke PK, Rectenwald J, Stanley JC, Upchurch GR Jr. Epidemiology of aortic aneurysm repair in the United States from 1993 to 2003. Ann N Y Acad Sci 2006; 1085:1-10

3 Hinterseher I, Tromp G, Kuivaniemi H. Genes and abdominal aortic aneurysm. Ann Vasc Surg 2011;25(03):388-412

4 Golledge J, Reeve T, Norman PE. Abdominal aortic aneurysm, inguinal hernias and emphysema. ANZ J Surg 2008;78(11):1034

5 Antoniou GA, Georgiadis GS, Antoniou SA, Granderath FA, Giannoukas AD, Lazarides MK. Abdominal aortic aneurysm and abdominal wall hernia as manifestations of a connective tissue disorder. J Vasc Surg 2011;54(04):1175-1181

6 Takagi H, Sugimoto M, Kato T, Matsuno Y, Umemoto T. Postoperative incision hernia in patients with abdominal aortic aneurysm and aortoiliac occlusive disease: a systematic review. Eur J Vasc Endovasc Surg 2007;33(02):177-181

7 Alcorn HG, Wolfson SK Jr., Sutton-Tyrrell K, Kuller LH, O'Leary D. Risk factors for abdominal aortic aneurysms in older adults enrolled in The Cardiovascular Health Study. Arterioscler Thromb Vasc Biol 1996;16(08):963-970

8 Kingsnorth A. The management of incisional hernia. Ann R Coll Surg Engl 2006;88(03):252-260

9 Pannu R, McPhail IR. Prevalence of abdominal wall hernia in participants with abdominal aortic aneurysm versus peripheral arterial disease-a population-based study. Angiology 2012;63 (02):146-149

10 Müller V, Miszczuk M, Althoff CE, et al. Comorbidities associated with large abdominal aortic aneurysms. Aorta (Stamford) 2019;7 (04):108-114

11 Abci I, Bilgi S, Altan A. Role of TIMP-2 in fascia transversalis on development of inguinal hernias. J Invest Surg 2005;18(03):123-128

12 Friedman DW, Boyd CD, Norton P, et al. Increases in type III collagen gene expression and protein synthesis in patients with inguinal hernias. Ann Surg 1993;218(06):754-760

13 Pascual G, Rodríguez M, Gómez-Gil V, Trejo C, Buján J, Bellón JM. Active matrix metalloproteinase-2 upregulation in the abdominal skin of patients with direct inguinal hernia. Eur J Clin Invest 2010; 40(12):1113-1121

14 Antoniou SA, Antoniou GA, Granderath FA, Simopoulos C. The role of matrix metalloproteinases in the pathogenesis of abdominal wall hernias. Eur J Clin Invest 2009;39(11):953-959
15 Liu J, Khalil RA. Matrix metalloproteinase inhibitors as investigational and therapeutic tools in unrestrained tissue remodeling and pathological disorders. Prog Mol Biol Transl Sci 2017; 148:355-420

16 Antoniou GA, Giannoukas AD, Georgiadis GS, et al. Increased prevalence of abdominal aortic aneurysm in patients undergoing inguinal hernia repair compared with patients without hernia receiving aneurysm screening. J Vasc Surg 2011;53(05):1184-1188

17 Pitoulias GA, Donas KP, Chatzimavroudis G, Torsello G, Papadimitriou DK. The role of simple renal cysts, abdominal wall hernia, and chronic obstructive pulmonary disease as predictive factors for aortoiliac aneurysmatic disease. World J Surg 2012;36(08): 1953-1957

18 Anderson O, Shiralkar S. Prevalence of abdominal aortic aneurysms in over 65-year-old men with inguinal hernias. Ann R Coll Surg Engl 2008;90(05):386-388

19 Pleumeekers HJ, De Gruijl A, Hofman A, Van Beek AJ, Hoes AW. Prevalence of aortic aneurysm in men with a history of inguinal hernia repair. Br J Surg 1999;86(09):1155-1158

20 Gue S. Development of right inguinal hernia following appendicectomy. A 10-year review of cases. Br J Surg 1972;59(05): 352-353

21 Henriksen NA, Helgstrand F, Vogt KC, Jorgensen LN, Bisgaard TDanish Hernia Database Danish Vascular Registry. Risk factors for incisional hernia repair after aortic reconstructive surgery in a nationwide study. J Vasc Surg 2013;57(06):1524-1530, 1530. e1-1530.e3

22 Megalopoulos A, Ioannidis O, Varnalidis I, et al. High prevalence of abdominal aortic aneurysm in patients with inguinal hernia. Aortic aneurysm in inguinal hernia patients. Biomed Pap Med Fac Univ Palacky Olomouc Czech Repub 2019

23 Borkon MJ, Zaydfudim V, Carey CD, Brophy CM, Guzman RJ, Dattilo JB. Retroperitoneal repair of abdominal aortic aneurysms offers postoperative benefits to male patients in the Veterans Affairs Health System. Ann Vasc Surg 2010;24(06):728-732

24 Laohapensang K, Rerkasem K, Chotirosniramit N. Left retroperitoneal versus midline transperitoneal approach for abdominal aortic aneurysms (AAAs) repair. J Med Assoc Thai 2005;88(05): 601-606

25 Takagi H, Umemoto T. A meta-analysis of the association of primary abdominal wall hernia with abdominal aortic aneurysm. Int Angiol 2015;34(03):219-228

26 van den Berg JC, de Valois JC, Go PM, Rosenbusch G. Detection of groin hernia with physical examination, ultrasound, and MRI compared with laparoscopic findings. Invest Radiol 1999;34(12): 739-743

27 Cannon DJ, Casteel L, Read RC. Abdominal aortic aneurysm, Leriche's syndrome, inguinal herniation, and smoking. Arch Surg 1984;119(04):387-389

28 Lehnert B, Wadouh F. High coincidence of inguinal hernias and abdominal aortic aneurysms. Ann Vasc Surg 1992;6(02):134-137

29 Hall KA, Peters B, Smyth SH, , et al. Abdominal wall hernias in patients with abdominal aortic aneurysmal versus aortoiliac occlusive disease. Am J Surg 1995;170(06):572-575, discussion 575-576

30 Adye B, Luna G. Incidence of abdominal wall hernia in aortic surgery. Am J Surg 1998;175(05):400-402

31 Wright DM, O'Dwyer PJ. Prevalence of aortic aneurysm in men with a history of inguinal hernia repair. Br J Surg 2000;87(01): 123-124

32 Musella M, Milone F, Chello M, Angelini P, Jovino R. Magnetic resonance imaging and abdominal wall hernias in aortic surgery. J Am Coll Surg 2001;193(04):392-395

33 Papadimitriou D, Pitoulias G, Papaziogas B, , et al. Incidence of abdominal wall hernias in patients undergoing aortic surgery for aneurysm or occlusive disease. Vasa 2002;31 (02):111-114 
34 Raffetto JD, Cheung Y, Fisher JB, et al. Incision and abdominal wall hernias in patients with aneurysm or occlusive aortic disease. J Vasc Surg 2003;37(06):1150-1154

35 Henriksen NA, Sorensen LT, Jorgensen LN, Lindholt JS. Lack of association between inguinal hernia and abdominal aortic aneurysm in a population-based male cohort. Br J Surg 2013;100(11): 1478-1482

36 Gindera LB, Donas KP, Torsello G, Bisdas T, Stavroulakis K. Significant CT-angiographic evidence of coexisting abdominal aortoiliac aneurysms with simple renal cysts and abdominal wall hernias. Minerva Chir 2015;70(06):409-416

37 Darke SG, Eadie DD. Abdominal aortic aneurysmectomy: followup and assessment of fifty-one survivors. J Cardiovasc Surg (Torino) 1973;14:478-483

38 Stevick CA, Long JB, Jamasbi B, Nash M. Ventral hernia following abdominal aortic reconstruction. Am Surg 1988;54:287-289

39 Johnson B, Sharp R, Thursby P. Incisional hernias: incidence following abdominal aortic aneurysm repair. J Cardiovasc Surg (Torino) 1995;36:487-490

40 Holland AJ, Castleden WM, Norman PE, Stacey MC. Incisional hernias are more common in aneurysmal arterial disease. EJVES 1996;12:196-200

41 Liapis CD, Dimitroulis DA, Kakisis JD, et al. Incidence of incisional hernias in patients operated on for aneurysm or occlusive disease. Am Surg 2004;70:550-552
42 Rodriguez HE, Matsumura JS, Morasch MD, Greenberg RK, Pearce WH. Abdominal wall hernias after open abdominal aortic aneurysm repair: prospective radiographic detection and clinical implications. Vasc Endovascular Surg 2004;38:237-240

43 Fassiadis N, Roidl M, Hennig M, South LM, Andrews SM. Randomized clinical trial of vertical or transverse laparotomy for abdominal aortic aneurysm repair. The British journal of surgery 2005 ; 92:1208-1211

44 Panayiotopoulos YP, Sandison AJ, Reidy JF, Adam A, Taylor PR. Endovascular repair of residual iliac artery aneurysms following surgery for ruptured abdominal aortic aneurysm. European journal of vascular and endovascular surgery: the official journal of the European Society for Vascular Surgery 1996;12:482-486

45 Bevis PM, Windhaber RA, Lear PA, Poskitt KR, Earnshaw JJ, Mitchell DC. Randomized clinical trial of mesh versus sutured wound closure after open abdominal aortic aneurysm surgery. The British journal of surgery 2010;97:1497-1502

46 Gruppo M, Mazzalai F, Lorenzetti R, Piatto G, Toniato A, Ballotta E. Midline abdominal wall incisional hernia after aortic reconstructive surgery: a prospective study. Surgery 2012;151:882-888

47 Wiegering A, Liebetrau D, Menzel S, Buhler C, Kellersmann R, Dietz UA. The incidence of incisional hernia after aortic aneurysm is not higher than after benign colorectal interventions: A retrospective control-matched cohort study. Gefasschirurgie 2018; 23:23-31 